\title{
THE CHANGING STRATEGIC PARADIGM IN THE BLACK SEA ZONE AND THE CHALLENGES TO REGIONAL SECURITY
}

\author{
Natalia Bekiarova \\ Prof. Ph.D., National Defense College, Sofia, Bulgaria, nataliab@abv.bg
}

\begin{abstract}
The article analyses Russia's particular actions aimed to alter the strategic balance in the Black Sea region in her favor. The 2008 war with Georgia and the increasing Russian presence in Abhazia, South Ossetia, Armenia, and Transnistria, in addition to the geopolitical quake(upheaval) that followed the Crimea annexation and the conflicts in Donbas supports our view. In assessing the military balance, a thorough comparison is made between the Russian Black Sea Fleet and that of Turkey, that shows the latter's superiority. The military balance is further tilted in Western favor, if one adds the naval forces of the other Black Sea countries, that are NATO members. This conclusion leads the author to stress the hypothesis of a Western/NATO plus USA domination of the region. Militarization, however, is self-destrutive, as it leads to higher security risks. In conclusion, several positive measures are proposed in order to minimize those security risks in the Black Sea region and to ease the tensions between the West and Russia.
\end{abstract}

Keywords: Black Sea region, militarisation, geopolitical balance.

\section{INTRODUCTION}

The 2013 Ukraine crisis signalled a long-term deterioration of the security environment affecting The European Union and NATO Southeastern flank. A set of negative trends, including the increasingly complicated US-EU relations in both the economic and political (endeavour) field, the deepening divide between the West and Russia, the lack of a combined effort willingness to overcome the Middle East conflicts, the U.S. unilateral withdrawal from the Intermediate-range Nuclear Forces treaty, in addition to the gradual diminution of the principles of international law and the inefectiveness of the UN mechanisms - all these factors put together concurred to facilitate the return of war as a legitimate instrument in international policies.

The article stresses the interplay and geopolitical rivalry between the great powers in both the political sphere and the arms race on the one hand, plus the festering security issues in particularly sensitive regional settings such as the European Southeast and particularly the Black Sea region, on the other. It is hence of no coincidence, that currently the Black Sea region is increasingly viewed as a likely war zone if and when the West versus Russia confrontation turns into a full-scale military conflict (2018a). Five years after the illigitimate Crimea and Sebastopol annexation and the inclusion of the peninsula into the Russian Federation which fueling the conflicts in Donetsk and Lugansk, the relations between the West and Russia are at their lowest point since the end of the Cold War with both sides competing over military supremacy further endangering peace in the region and in Europe. 


\section{THE NEW GEOPOLITICAL BALANCE}

The focus on the Black Sea security challenges is the result of several reasons. Most important among them is the geopolitical setting (status quo) which defines the region and its immediate geographical neighborhood the Caspian Sea area - as a pivot of importancee between two continents. The Black Sea region is the closest area to the conflicts-ridden Middle East, the Gulf and the Indian subcontinent; it is bordering Central Asia, Afghanistan, Syria, Iraq, Iran, etc., which the renewed great power competition turned into a highly contested area. The Black Sea region cvan be considered as a "civilisational barrier" between the neighboring worlds of Islam and Christianity.

In terms of energy security the whole world is considered as an important hub of oil and gas transportation routes corridors and streams. It is of great importance to Russia, whose resource-centered economy has a justification for closing the pipelines crossing the Moscow-controlled territories. On the other hand, however, there is a growing trend in diversification of both the sources and the transportation routes in exporting hydrocarbons to the European Union.

These opportunities give the bigger states bordering the Black Sea an impetus to seek a dominant position in the region thus securing for themselves a further geopolitical edge in the Balkans, Central Europe, South Caucasus, the Eastern Mediterranean, and the Middle East.

The region's role in bridging continents and civilisations is considered to be a particular important reason for Russia's obsession of imposing its domination over it. It is a part of a traditional Russian imperial policy introduced by Peter the Great and Catherine the Great, which could be summed up by the adage „he who controls the Black Sea zone could impose its interests in the subregions of Southern Caucassus, the Balkans, in addition to the Mediterranean".

Currently there is a trend among Russian experts to underestimate the Black Sea importance claming that its potential is limited owing to its being "a closed sea" which is particularly vulnerable to surveillance by modern military hardware. However, previous attempts to ignore, its geopolitical and geoeconomic role came to a standstill after the Russian intervention in the Syrian crisis (2018b).

The disintegration of the Soviet Union and the ensuing Russian attempts to restore its influence and achieving leading positions in the Black Sea region and in South Caucassus revitalised the so-called "frozen conflicts" in Georgia (Abkhazia and South Ossetia), Azerbaidjan (Nagorni Karabakh), and Moldova (Transnistria). Russia is a key player and mediator in the efforts to reach a settlement in all these conflicts. As early as July 21,1991 Moscow was instrumental in achieving a peace deal in Transnistria. It was the Kremlin that secured the permanent stationing there of peacekeeping force with unified command, comprising 5 Russian battalions, flanked by 3 Moldovan and 3 Transnistrian battalions. It was also Russia that played the leading role in reaching an agreement on ending the Georgian-Ossetian conflict; the legally binding document to that effect was signed on June 24, 1992 in Sochi by the presidents Boris Yeltsin and Edward Shevardnadze. The end of the military phase of the conflict was (to be) followed by the establishment of a Mixed Control Commission which includes Russians, Georgians, and South Ossetians. Another conflict - the Georgian-Abkhazian feud was terminated, albeit temporarily, with the signing on May 14, 1994 of „The Moscow Agreement”.

And it was again with Russian mediation, that „The Bishkek Protocol” was signed in Kirgizstan's capital on May 5, 1994 - it states that an armistice between Armenia, Azerbaijan, and the Republic Nagorno-Karabakh will be effective after May 5, 1994. It is now still enforced successfully despite the recurring tensions in the sub-region.

Russia had a different approach to each of the "frozen conflicts". Moscow actively supports the citizens of the separatist regions in Transnistria, Abkhazia, and South Ossetia; since the late 1990s they are offered Russian passports and Russian citizenship. Those who have worked in the Soviet Union were eligible to receive Russian pensions. Moscow also supported the separatist regimes with direct aid providing financial support and materials, especially hydrocarbons. These territories also benefitted from assistance in the form Russian peacekeeping force. As for the Republic of Nagorno-Karabakh, Moscow does not provide a direct aid; instead aid is funneled with the intermediary of Armenian government. Needless to say, Armenia is the most pro-Russian country in the South Caucasus region and is a member of the Organization of Collective Security Treaty since its establishment back in 1992.

The following years did not witness real solutions to the frozen conflicts. The OSCE Minsk Group, which was established back in 1992 with the aim of solving the Armenian-Azeri conflicts was not successful. Gradually, the deepening confrontation between the West and Russia casted a shadow on these suspended conflicts hence making their resolution more difficult (Bekiarova, 2017a). 
The next step in widening Russian influence in the Black Sea region was made during the first tenure of president Putin, who opted for a return to a more "tough" foreign policy. The 2008 Russian-Georgian War was the direct result of this new course. The economic growth achieved in the first decade gave substance to the Russian claims to uphold its interests in the world and to seek a great power status.

The most important stage in implementing Moscow's expansionist policies aimed at restoring Russian influence in the former Soviet republics was the annexation of Crimea and its military involvement in the conflicts in the separatist regions of Lugansk and Donetsk.

Experts stress on Russia's intention to create "gray zones" of instability along the borders of its neighbors within the post-Soviet space in order to make difficult their accession to NATO and the European Union (2017b).

Another step of widening Russian influence to the East and eventually to secure its access to the Mediterranean was Moscow's direct military intervention in the Syrian conflict.

All those developments led to altering of the geopolitical power balance along NATO/EU Southeast flank. There are sufficient proof for these new developments that concern the Black Sea's northeastern coast. Moscow recognised the independence and the seccesion of the Georgian regions of Abhazia and South Ossetia, which eventually fell under Russian domination, although legally they are still a part of the Georgian state. In 2010 the Kremlin signed treaties with the officially recognised by Russia separatist republics and built there two modern military bases, thereby asserting its political domination over these territories. The fourth Russian base is located in South Ossetian capital Tsinhvali, while the seventh Russian base is situated in Abhazia and its command headquaters resides in the city of Gudauta. The two bases have between them over 8000 soldiers and pertain are assigned to the Southern military district of the Russian Federation. The Russian bases were established there for a period of 49 years, but the treatises provide for an indefinite number of automatic 15-year prolongations of the Russian military presence upon the expiration of the previous period. On November 24, 2014 Russia and Abhazia signed a Treaty for cooperation and strategic partnership, which provides for the establishment of a common defence and security space by the two states and the formation of combined military forces. The next year,that is, on March 17, 2015 Russia and South Ossetia signed a treaty for comprehensive cooperation.

As is well known, during the Georgian-Russian War the Georgian military fleet with all its naval infrastructure were completely destroyed by the Russian aviation.

Currently the Georgian Ministry of Defence is making efforts, with the help of the USA and other NATOmembers, to rebuild its military naval forces and infrastuctures. It has acquired several patrol vessels, but there is yet a long way ahead in building a modern fleet with all its essential infrastructure.

These arrangements made which do not conform to international law, led to a de facto Russian control over almost half of the Black Sea waters. But more was yet to come. During the Ukraine crisis and following the Crimea annexation most of the Ukrainian Black Sea Fleet, stationed at Sebastopol, passed into Russian hands. After that with only a few vessels left in Odessa's harbor the Ukrainian navy ceased to be a credible naval force.

Russia was successful in widening its influence in other countries in the South Caucassus region. The 102 Russian base was moved near the town of Gumri, Armenia, in and added to the already existing aviation force at the "Erebuni" airbase near the capital Erevan. These Russian military units were established by reforming the already stationed there Russian troops according to the 1995 Russian-Armenian Treaty. Initially, the Russian soldiers were given fighting assignements within the framework of the United system for anti-aircraft defence of the Community of Independent States. On August 20, 2010, during the visit of the then president Medvedev in Armenia a new treaty was signed, which stipulates that the period of stationing of the Russian military in this country was extended until 2044. A Memorandum was signed pertaining to the issue of relations between the Federal Service for military-technical cooperation of the Russian Federation and the Ministry of Defence of Armenia. According to the new treaty the Russian military in a joint effort with the military forces of Armenia will provide guarantees for the country's security patrolling the Armenian borders with Iran and Turkey. This leads to that any future agression against Armenia is to be considered an agression against Russia (2012a). The Russian military influence is also spreading within the Transdnistria Moldovan Repulic, where 1200 Russian military are permanently stationed.

In what concerns the follow-up to the Crimea annexation by the Russian Federation, Moscow took hold of this strategically important peninsula and its highly important ,from a military point of view, gulfs of Sebastopol and Balaklava. The annexation of the Crimea and Sebastopol tripled the length of the Russian coastline - from $475 \mathrm{~km}$ to $1200 \mathrm{~km}$, i.e. aproximately one quarter of the whole coastline length. 
It is still less that the coastline length of Turkey - Russia's main Black Sea competitor, which is approximately $1785 \mathrm{~km}$ or $35 \%$ of the overall Black Sea coastal length (2018c). In parallel with the territorial expansion in the Black Sea region, Russia also acquired an access to the hydrocarbon fields discovered in her territorial waters.

Currently Russia enjoys an absolute territorial and military domination over the Azov Sea, which is accessible only through the narrow strait of the Gulf of Kerch while both of its coasts are now within Russia's territory. This domination was further asserted following the building and the inauguration on May 16, 2018 of the "Crimea Bridge" (2018d), when the exploitation of the bridge began all the transport links, communications, of the entire territorial, sea and air control are detained by Russia. This is to say, that currently Moscow has the power to deny the access to these areas and to isolate them from the rest of the world.

The fact that the whole of the Gulf of Kerch is within Russian control.The Gulf of Kerch is of key importance because of the fact that it opens the access to the Russian Krasnodar region to the east, and to the Russian ports of Novorosiisk and Soch to the south. One should bear in mind, that Novorosiisk is the largest Russian trade port on the Black Sea and that it is the hub of huge oil and gas pipelines, linking the Black Sea and the Caspian Sea (2018e). The Gulf of Kerch itself is the door to a great number of internal river routes of Russia linked through the Volga-Don channel, with the Black Sea and the Azov Sea. The Volga River is debouching into the Caspian Sea, and that provides an opportunity for linking the two seas.

\section{THE NEWLLY EMERGING MILITARY BALANCE}

Initially Russia gained an access to the Black Sea after one of her wars with the Ottoman Empire which she won thus forcing the Turks to sign the Kuchuk Kainarji Treaty in 1774. Russian military presence there dates from the reign of Ekaterine the Second, when on May 13, 1783 the first units of the Russian Black Sea Fleet were completed (2018f). This step was the first act of the century long Russian imperial strategy of securing an access to a warm sea and a military presence the vicinity to the Straits and the Mediterranean, which was considered as a sine qua non for the future success of Russia's successful interventions in the straggle for control over the Near and Middle East, the Balkans and South Caucassus.

Before the Crimea annexation in 2014 Russia's Black Sea Fleet had at its disposal one task force of surface vessels, of which the main unit was the cruiser "Moscow”. The task force had also at its disposal landing vessels, missile boats, two submarines which in addition to standard weaponr, have capabilities for launching cruise missiles, 2 units for patrolling the territorial waters of Sebastopol and Novorossiisk, units of intelligence-gathering ships, in addition of a batch of auxilliary vessels. The Naval Aviation of the Russian Black Sea Fleet is enhanced with a nmber of $\mathrm{Ka}-27$ and Mi-14 helicopters, in addition to Ka-29 helicopters for the support of the local marine corps and of a combat wing of bombers Su-24. The combined strenght of the Russian Black Sea Fleet is aproximately 12500 soldiers (2018g). In 2011 the former Commander of the fleet admiral Vladimir Komoedov frankly admitted that the Turkish side has a 4,7 fold superiority over the combined fleet of the Ukraine and Russia (2018h).

Five years later, and despite the sanctions' regime introduced by Western states in response to the Russian agression against Ukraine, the strategic military balance in the Black Sea basin tilted in favor of Russia - in addition to the growth of the fighting capabilities of its fleet, its overall organisation was modernised and an extraordinary active Russian information campaign was activated (2015a).

Following the Crimea annexation Russia undertook to modernise its old military fleet in addition to acquiring modern-day ships and military hardware. The most important dimension in this effort was the replacement of the old missile complexes of the military vessels with new ones. Another is the transfomation of the existing airbases, which service the naval forces.

According to open sources, during 2018 the number of men serving in the Black Sea fleet grew by approximately 32 thousand new recrutees (2018i).

Although back in 2010 president Putin announced a rearmament program for the period 2011-2020, even before it expired, a new program was launched in 2018 to be completed in 2025. It stresses the development of the strategic nuclear forces, the introduction of highly-accurate weapons, the widening of the intelligence potential, in addition to the Russian type of "Star Wars" program and in general - the introduction of newest technologies to the military sector. Meanwhile the Black Sea Fleet received a sizable quantity of new vessels, armament and military hardware. They include six new diesel submarines of the type 877 "Paltus" and above all the new frigates of the type 11356 nicknamed „the three admirals”: „Admiral Grigorovich”, „Admiral Essen”, and „Admiral Makarov”, armed with the newest Russian multipurpose cruise missiles „Kalibr” with a range of $2500 \mathrm{~km}$. The latter are so built as to destroy land and sea targets, such as surface 
vessels and submarines. The fleet also received six 1300-ton patrool ships, armed with cruise missiles with a range of action depending on specific targets. These are flanked by six smaller missile ships of the project 21631 „Buyan-M”, which are specialised in missions along coastal waters. By 2022 another batch of six small missile ships of the type 22800 "Karakurt" armed with anti-aircraft weapons, are also expected to join the fleet.

It was this ambitious rearmament and modernisation effort that altered the balance of power. Currently Crimea is home of the most state of the art Russian anti-aircraft complex C- 400 "Triumf" with a range of up to $400 \mathrm{~km}$, in addition to the coast missile complex "Bastion P" with a range of 350 to $400 \mathrm{~km}$, which can destroy both sea and land targets. The Russian side was also enhanced with a new military aircraft of the type Su-30SM, the anti-submarine bombarders Tu-142 and II-38' in addition to helicopters, tanks and other types of transportation and support hardware. Within a two-year period the creation of two new brigades for coastal defence is progammed, these are expected to be stationed near Sebastopol and Novorossiisk and will service the aviation in the zone of the Black Sea comprising two big airfields with 38 airplanes and 44 helicopters (2018i).

Despite Russia's swift military build-up, however, Turkey contines to be the dominant force in the Black Sea. Other sources, such as the authoritative publication „Global Firepower”, rank Russia first (2018j). More accurate expert soources, however, point to the fact that Ankara still enjoys an edge with its 69 naval vessels and 14 submarines. Turkey doesn't have cruisers, but has at its disposal 16 frigates, some of which are made in Australia and considered to be modern battle ships. As for the Turkish submarines which are coined after the German modernised (project 209); only four of them are up to date and named the "Gur" class, armed with American missiles of the "Harpoon" type. In 2009 Turkey signed contracts with German and British military companies for additional six new submarines (project 214), which are to be delivered between 2018 and 2023 (2018k).

We must always keep in mind the fact that regardless of the mutually beneficial Russian-Turkish economic cooperation, Turkey is a loyal member of NATO and allied with the other member-states from the Black Sea region. When we consider the military balance in the Black Sea we must consider also the US forces, which declared the Black Sea "a zone of the vital interests of the USA" (2018I). If we add the Bulgarian naval force (17 vessels) and the Romanian fleet (19 vessels and one submarine), there is a clear NATO superiority visà-vis Russia's forces $(2018 \mathrm{~m})$. Responding to the Russian drive for naval domination, the US also increased their military forces along the borders with Russia in both the Baltic republics and in the Black Sea region. At the 2014 NATO summit in Wales the participants stressed the necessity of strenghtening the Alliance's prescence along its Eastern borders. Since the end of 2015 an anti-aircraft base was established in Romania. During the last years we have witnessed an increase of the American troops stationed in Romania and Bulgaria to service the aircraft support of the bases located there. There also have been efforts to widen the military infrastructure in these countries. A multinational brigade numbering 5000 soldiers will be stationed in Romania, in addition to the existing four NATO international batalions in Poland, Lituania, Estonia and Latvia.

One should also take into consideration the enormous capabilities of the US vessels and aircraft carriers in the Mediterranean, despite the existing limitations for entering the Black Sea under the Montreux Convention, still in force (The Montreux Convention (1936), does not allow warships of non-regional countries in the area of The Black Sea for more than 21 days. The passage through the Bosporus and the Dardanelles of aircraft carriers and submarines to countries that do not border the Black Sea is prohibited. There are restrictions in terms of tonnage of seagoing vessels, too. Convention regarding the regime of the straits signed at Montreux, july 20 th, 1936) (2018n).

During the last few years there is a $30 \%$ rise in the number of the exercises and training missions of the naval and air patrools of both Russia and NATO in the Black Sea. The military arms race between NATO and Russia has spiralled dangerously as the real risks from mistakes, escalation of tensions and unwarrented situations could eventually cause a direct conflict. There is a rising number of nearly avoided incidents due to provocations along the air and maritime borders in the Black Sea basin. In the span of only one week in the beginning of August 2018 there were reports about three cases of intercepting of NATO airplanes by Russian airplanes over the Black Sea (20180). One should also take note of the November 5 , 2018 incident in which a Russian Su-27 flying in close vicinity of a US fighter dangerously intercepted the American reconnaissance military plane FP-3F "Aries" in international airspace above the Black Sea (2018p, Terziev, Petkov, Krastev, 2018q-z).

\section{CONCLUSION}

Previous experience shows that arms race always has as its outcome the introduction of new types of arms: 
more modern, more expensive and deadlier than the older ones. When one compares the current situation to the Cold War, thing we believed until recently to be defunct, the contemporary confrontation between NATO and Russia shows that the present situation is much more complex, fluid, and hard to control. We share with other experts the hope that a military conflict is still avoidable. However, the security risks in the region are very much alive, they represent a projection of the continuing arms race which is self-destructive.

In order to safeguard peace and stability in the Black Sea area it is imperative to put an end to militarisation and undertake concrete initiatives for keeping confrontation under control. New measures are needed to avoid incidents. NATO should propose a restriction in the number of ground forces and military hardware of both NATO and Russia plus a set of measures to keep mutual threats under control. A logical step should be to renew and re-activate the NATO-Russia format which could be instrumental in introducing new inititatives for limiting military activities in the Black Sea zone, and in strenghtening the role of the international status of the Organization for Security and Cooperation in Europe, there should be a number of "small" steps, which could pave the way for restoring mutual confidence and stability in the region.

\section{REFERENCE LIST}

O'Connor, Tom. Russia and NATO War Games Raise Tensions in Black Sea. (2018a). https://www.newsweek.com/russia-nato-war-games-raise-tensions-black-sea-575805.

Savin, Leonid. Russian Security Frame For Black Sea Region. (2018b). https://www.geopolitica.ru/en/article/russian-security-frame-black-sea-region.

Bekiarova, Natalia. (2017a). The Regulation of the "Frozen" conflicts in the Post-Soviet space - A hostage of confrontation between the West And Russia. Modern security and defence challenges. G. S. Rakovski National Defense College, Part 2, 2017, pp.74-79.

Bekiarova, Natalia. (2017b). Tне Growing Military Activity In The Black Sea Region As A Security Threat. Strategic Impact No. 1[62]/2017, pp. 44-54, ISSN 1842-9904 (on-line); ISSN-L 1841-5784.

Bekiarova, Natalia. (2012a). Nagorno-Karabakh between Armenia and Azerbaijan, Georgi Rakovski Military Academy, 2012, pp. 221-222.

Russia and Turkey in the Black Sea and the South Caucasus. (2018c). Europe Report N 250, 28 June 2018. p.17.

Gvosdev, Nikolas. (2018d). Russia's Strategy In The Black Sea Basin https://warontherocks.com/2018/08/russias-strategy-in-the-black-sea-basin/.

Chossudovsky, Michel. (2018e). Crisis in Ukraine: Russia Extends its Control over the Black Sea and Strategic Waterways. https://www.globalresearch.ca/russia-extends-its-control-over-the-black-seaand-strategic-waterways/5374021.

Черноморский Российский флот. (2018f). http://www.ote4estvo.ru/eto-interesno/1683-chernomorskiyrossiyskiy-flot.html.

Militarization Of Occupied Crimea - A Threat To Global Security. (2018g). http://defenceua.com/index.php/en/publications/defense-express-publications/914-militarization-of-occupied-crimeaa-threat-to-global-security.

Vladimir Komarov. The Turkish fleet is almost 5 times stronger than the Russian fleet. (2018h). http://www.mk.ru/politics/2011/11/10/641804-turetskiy-flot-pochti-v-5-raz-silnee-flota-rossii.html.

Arencheva, llina. (2015a). Aspects of Policies and Strategies for Cyber security in EU. Journal of Defense Resources Management, 6, 2015, 2, pp. 37-44.

Gorenburg, Dmitry. Is a new Russian Black Sea Fleet coming? Or is it here? (2018i). http://www.ponarseurasia.org/article/new-russian-black-sea-fleet-coming-or-it-here.

Russia Military Strength. (2018j). https://www.globalfirepower.com/country-military-strengthdetail.asp?country_id=russia.

Delanoe, Igor. (2018k). Соотношение вооруженных сил в Черноморском регионе. 
http://russiancouncil.ru/activity/digest/longreads/sootnoshenie-vooruzhennykh-sil-v-chernomorskomregione-/?sphrase_id=237996.

Petersen, Alexandros. Black Sea Security: The NATO Imperative. (2018I).

https://www.wilsoncenter.org/publication/black-sea-security-the-nato-imperative.

Military Balance in the Black Sea Region. (2018m). http://russiancouncil.ru/en/blackseamilitary.

http://sam.baskent.edu.tr/belge/Montreux_ENG.pdf. (2018n).

The British Typhoons have made an interesting close encounter yesterday: a quite rare $\mathrm{Be}-12$ Chaika. (20180). https://theaviationist.com/2018/08/26/russian-navy-beriev-be-12-amphibian-aircraftintercepted-by-raf-typhoons-over-the-black-sea/.

Russian fighter jet intercepts US Navy plane. (2018p). https://edition.cnn.com/2018/11/05/politics/russianfighter-jet-intercepts-us-navy-plane/index.html.

Terziev, V., Petkov, M., Krastev, D. (2018q). Operative mode for police cooperation between the member states of the European Union. // Proceedings of SOCIOINT 2018- 5th International Conference on Education, Social Sciences and Humanities, 2-4 July 2018- Dubai, U.A.E, International Organization Center of Academic Research, www.ocerints.org, pp.473-476, ISBN: 978-605-82433-3-0.

Terziev, V., Petkov, M., Krastev, D. (2018r). European arrest warrant: appearance and preferences for fulfillment. // Proceedings of SOCIOINT 2018-5th International Conference on Education, Social Sciences and Humanities, 2-4 July 2018- Dubai, U.A.E, International Organization Center of Academic Research, www.ocerints.org, pp. 477-481, ISBN: 978-605-82433-3-0.

Terziev, V., Petkov, M., Krastev, D. (2018s). Eurojust casework on mafia-type criminal organisations. // Proceedings of SOCIOINT 2018- 5th International Conference on Education, Social Sciences and Humanities, 2-4 July 2018- Dubai, U.A.E, International Organization Center of Academic Research, www.ocerints.org, pp.487-491, ISBN: 978-605-82433-3-0.

Terziev, V., Petkov, M., Krastev, D. (2018t). Concept of joint investigation teams. // Proceedings of SOCIOINT 2018- 5th International Conference on Education, Social Sciences and Humanities, 2-4 July 2018- Dubai, U.A.E, International Organization Center of Academic Research, www.ocerints.org, pp.492-496, ISBN: 978-605-82433-3-0.

Terziev, V., Petkov, M., Krastev, D. (2018u). European arrest warrant and human rights of the accused. // Proceedings of SOCIOINT 2018- 5th International Conference on Education, Social Sciences and Humanities, 2-4 July 2018- Dubai, U.A.E, International Organization Center of Academic Research, www.ocerints.org, pp.501-504, ISBN: 978-605-82433-3-0.

Terziev, V., Petkov, M., Krastev, D. (2018v). Pumps for the action on the European Union in the scope of the European agenda on security. // Proceedings of SOCIOINT 2018- 5th International Conference on Education, Social Sciences and Humanities, 2-4 July 2018- Dubai, U.A.E, International Organization Center of Academic Research, www.ocerints.org, pp.497- 500, ISBN: 978-605-82433-3-0.

Terziev, V., Petkov, M., Krastev, D. (2018w). The process of forming a criminal policy of the European Union. // Proceedings of SOCIOINT 2018- 5th International Conference on Education, Social Sciences and Humanities, 2-4 July 2018- Dubai, U.A.E, International Organization Center of Academic Research, www.ocerints.org, pp.505-510, ISBN: 978-605-82433-3-0.

Terziev, V., Petkov, M., Krastev, D. (2018x). Organization on the European Union in the sphere of penal preparation. // Proceedings of SOCIOINT 2018-5th International Conference on Education, Social Sciences and Humanities, 2-4 July 2018- Dubai, U.A.E, International Organization Center of Academic Research, www.ocerints.org, pp.482-486, ISBN: 978-605-82433-3-0.

Terziev, V., Petkov, M., Krastev, D. (2018y). Sources of European Union law. // Proceedings of SOCIOINT 2018- 5th International Conference on Education, Social Sciences and Humanities, 2-4 July 2018Dubai, U.A.E, International Organization Center of Academic Research, www.ocerints.org, pp.511516, ISBN: 978-605-82433-3-0.

Terziev, V., Petkov, M., Krastev, D. (2018z). The „Source of law“ category. // Proceedings of SOCIOINT 2018- 5th International Conference on Education, Social Sciences and Humanities, 2-4 July 2018Dubai, U.A.E, International Organization Center of Academic Research, www.ocerints.org, pp.517521, ISBN: 978-605-82433-3-0. 